\title{
Abbreviations for Spenser's Works
}

\author{
Amor Amoretti \\ Ast Astrophel \\ $\mathrm{CCH}$ Colin Clouts Come Home Againe \\ DS Dedicatory Sonnets to The Faerie Queene (1590) \\ Epith Epithalamion \\ FH Fowre Hymnes \\ FQ The Faerie Queene, Hamilton's second edition (2001; 2007) \\ $H B$ An Hymne in Honour of Beavtie \\ HL An Hymne in Honour of Loue \\ HHL An Hymne in Honour of Heauenly Loue \\ $\mathrm{HHB}$ An Hymne in Honour of Heauenly Beavtie \\ Letters Three Proper... Letters. Two ... Commendable Letters \\ MHT Prosopopoia. Or Mother Hubberds Tale \\ Prose Spenser's Prose Works, Variorum Edition, ix (1949) \\ Proth Prothalamion \\ RT The Ruines of Time \\ SC The Shepheardes Calender \\ TM The Teares of the Muses \\ $V G$ Virgil's Gnat \\ View A Vewe of the Presente State of Irelande \\ VP The Visions of Petrarch \\ Yale Yale Edition of the Shorter Poems (1989)
}

